\title{
Analysis of the Body Conditions of Free Grazing Cattles using Global Positioning System (GPS)
}

\author{
Choi Eun Gyu, Sang Yoon Lee, Myeong Hun Kim, Ki Yeon Kim ${ }^{1}$, \\ Han Jong $\mathrm{Ko}^{2}$ and Hyeon Tae Kim*
}

\author{
Department of Bioindustrial Machinery Engineering \\ Gyeongsang National University (Institute of Agriculture and Life Science) \\ Jinju, 660-701, Korea
}

\begin{abstract}
In the current work, GPS system was used to follow the movements and location of Korean native cattle in open pasture land and to study their pregnancy. The results showed that there were distinct differences in active mass for a day between pregnancy, non-pregnancy, early pregnancy and late pregnancy of the cattle. Based on the experimental results, the pregnancy and non-pregnancy in cattle could be predicted by analysis of the active mass and pattern using GPS. Using such data in real time at stockbreeding farmhouses, the bio-symptoms of Korean native cattle could be judged and subsequent actions can be taken rapidly in urgent situations.
\end{abstract}

Keywords: Analysis, body condition, cattle, free grazing, GPS

\section{INTRODUCTION}

Most livestock that used to live in the wild had been domesticated by human at some point, and they are raised for nutrition supply, including animal protein (Chun, 2004). In recent years, livestock research has become an important area in terms of food-, energy-, medicinesupply along with the advancement of economy of a country. In this regard, the overall research on feeding and management of livestock emphasized the aspect of economic efficiency mainly with respect to productivity (Hirakawa, 2006). To meet the criteria of consumer safety and high quality of food, especially after by BSE or AI, it has been suggested to rear the livestock in natural environment (Hirakawa, 2006). Moreover, leaving the cattle to graze by themselves in pastures, certainly help in reducing manpower (Kohari, 2006). However, certain problems regarding management of diseases and breeding arise, when the livestock are reared in natural conditions (高橋, 2006).

With respect to the production of fat and bulky cattle, along with the problems in dairy industry pasturing is an ideal rearing method, which reduces manpower, reduces excrement handling problem and promote animal welfare. However, such rearing process requires appropriate feeding and breeding management. Artificial insemination for breeding should target inducing pregnancy during the mating season. Many dairy farmers manage the breeding of fattening cattle and beef cattle at pastureland using a pedometer (吉岡, 2004). A pedometer may have a deviation by about one step but the main disadvantage is that a

\footnotetext{
Department of Industrial Health, Catholic University of Busan, Busan, Korea

Division of Livestock Policy, Jeju Special Self-Governing Province, Jeju, Korea

Corresponding Author: bioani@gnu.ac.kr
} 
moving range cannot be measured. The magnitude of the extra energy expenditure associated with activities of cattle, as well as its effect on animal production, is unknown and has been under controversy for the last 25 years. It is not known how the extra energy expenditure associated with activity is partitioned between forage harvesting and walking. The main feeding systems, such as ARC (1980), CSIRO (1990), AFRC (1993) and the Cornell System (Fox et al., 1992) control maintenance in grazing animals using information obtained from experiments carried out indoors in calorimeters or respiration chambers. According to these experiments, walking may considerably increase energy expenditure of grazing animals (Clapperton, 1964; Graham, 1964; Ribeiro et al., 1977). However, several workers did not find a negative effect on animal production or feed intake due to the activity of walking (Lamb et al., 1979; Nicholson, 1987; Thomson \& Barnes, 1993; Gemeda et al., 1995). It is also suspected that energy expenditure of walking could be overestimated, since animals walking on a treadmill could exhibit higher energy expenditure than those walking in the open range (Graham, 1964; Havstad \& Malechek, 1982). In this research, attempts have been made to check energy expense of the cattle during the mating season, pregnancy and disease of Korean native cattle.

Recently, GPS is utilized widely in biology, including movement tracking and observation of wild animals and fishes (OTANI, 2005; Harbin, 1995; Agouridis, 2004). A lot of studies are proceeding to track the action hunting and eating characteristics of cattle and animals on pasture land (Barbari, 2006; Eva Schlecht, 2006; Eva Schlecht, 2004; Ganskopp, 2001; Jeffrey, 2001; Eugene, 2005; CHOWDAPPA, 2005). To the best of our knowledge, the above-mentioned research work were the only instances used to check and track the movement and location of livestock or animals. There are no other studies to grasp the movement and body change of livestock through location chase till now.

The current research, accordingly, tried to grasp the location chase and active mass and to analyze the body changes through it.

\section{METHODOLOGY}

\section{Global Positioning System (GPS)}

GPS, originally developed for military navigation, is nowadays used in various fields, such as land surveying, measuring, geophysics and weather. The application fields of GPS were diversified since 1980. In the industrial sector, demand of car navigation, ubiquitous computing and GIS are increasing, and it is applied to various fields for accuracy position determination and geodetic reference system in academic field.

In this work, GPS (eXplorist610 Magellan ${ }^{\circledR}$ ) was attached to pregnant and non-pregnant Korean native cattle on the assumption that the mating season, pregnancy and disease can be diagnosed. We analyzed the active mass and pattern using the received data, which was stored through GPS for 24 hours. We collected the data of the Korean native cattle as they moved through the pasture land by hanging a GPS necklace on the neck of the cattle. The data were then collected for a few minutes after they came back to cattle shed to confirm that the instrument was operating normally. The following day, we collected the GPS necklace from the Korean native cattle and stored the data files on a computer.

From the collected data, the active mass and behavior pattern were analyzed of both pregnant and non-pregnant cattle. 


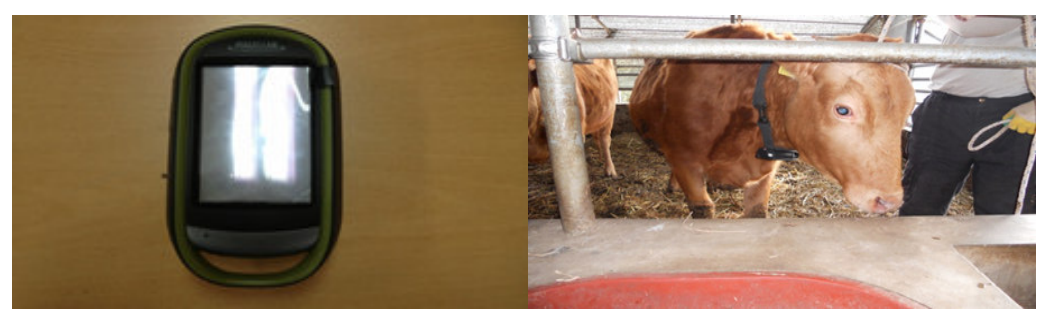

Fig.1. Photo of GPS for the cattle.

\section{Tested cattle and locations}

For the Korean native cattle tested, we selected the same-aged cattle to check the same condition of pregnancy and non-pregnancy, followed by testing the two heads of the cattle. We recorded the time and location data at scheduled time and continuously collected location information. Using the location information data, we aimed to analyze the relationship between the cattle's behavior and location and find out a method to diagnose pregnancy and birth time that we could not obtain using the existing method.

Research was performed in the domestic pasture lands in Jeju, Chuncheon-city and Boeungun during different grazing time and location. Although, continuous experiment was tried to be done at a single location, it was difficult due to stock farms. Fig. 2 shows the farms and pasture lands used for our experiments.
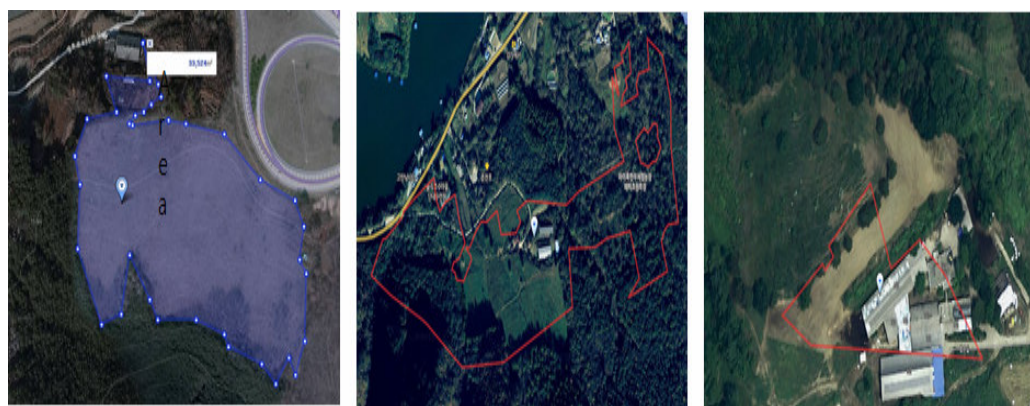

Fig.2. Photos of the pasture lands for experimental activities of cattle.

Table 1. The basic information of the three tests for the current work

\begin{tabular}{l|l|l|l|l|l|l}
\hline Location of test & \multicolumn{2}{|l|}{ Jeju } & \multicolumn{2}{l|}{ Chuncheon } & \multicolumn{2}{l}{ Boeun } \\
\hline Age(years) & 4 & 4 & 5 & 7 & 4 & 5 \\
\hline Pregnancy or not & $\mathrm{O}$ & $\mathrm{X}$ & $\mathrm{O}$ & $\mathrm{X}$ & $\mathrm{O}$ & $\mathrm{O}$ \\
\hline Weight(kg) & $\begin{array}{l}\text { About } \\
300\end{array}$ & $\begin{array}{l}\text { About } \\
250\end{array}$ & $\begin{array}{l}\text { About } \\
420\end{array}$ & $\begin{array}{l}\text { About } \\
400\end{array}$ & $\begin{array}{l}\text { About } \\
450\end{array}$ & $\begin{array}{l}\text { About } \\
500\end{array}$ \\
\hline Breed & Korean cattle & Korean cattle & Korean cattle \\
\hline $\begin{array}{l}\text { Experimental period } \\
\text { From 27 Feb. 2013 } \\
\text { to 3 Mar. 2013 } \\
\text { (about 5 days) }\end{array}$ & $\begin{array}{l}\text { From 13 Jul. 2013 } \\
\text { to 16 Jul. 2013 } \\
\text { (about 4 days) }\end{array}$ & $\begin{array}{l}\text { From 20 Jul. 2013 } \\
\text { to 23 Jul. 2013 } \\
\text { (about 4 days) }\end{array}$ \\
\hline $\begin{array}{l}\text { Average of outdoor } \\
\text { temp. \& RH }\end{array}$ & $7.7^{\circ} \mathrm{C}, 71.5 \%$ & 23.4 ${ }^{\circ} \mathrm{C}, 89 \%$ & $26.1^{\circ} \mathrm{C}, 83.9 \%$ \\
\hline A season & Spring & Summer & Summer \\
\hline
\end{tabular}


We grazed the tested cattle after birth in natural condition, and observed the mating season during rearing at a cattle shed. We could not determine the exact time of artificial insemination, because of it was difficult to observe the estrus in natural grazing conditions. In this research, therefore, we grazed cattle with GPS to judge the appearance of the estrus and further check for pregnancy. Fig. 3 shows a tested cattle moving to the pasture land.

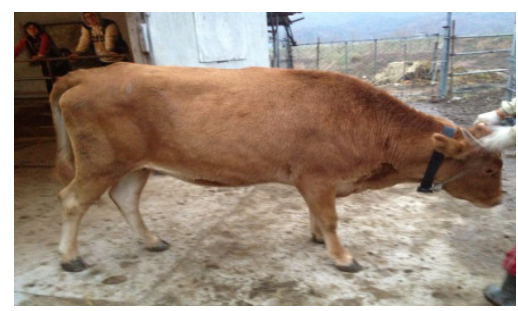

Fig.3. Picture of a Korean cattle with GPS.

\section{Experimental plan and Methods}

We stored the location information when the cattle moved and checked the moving route on pasture land using the collected location information.

$$
D=\sqrt{(M \cdot d P)^{2}+(N \cdot \cos P \cdot d R)^{2}}
$$

We tracked the moving route after we attached GPS to pregnant cattle from the three areas, as shown in Table 1 to observe their behavior while moving with the general cattle in spring at $7.7^{\circ} \mathrm{C}$ average temperature and $71.5 \%$ humidity, and in summer at $23.4{ }^{\circ} \mathrm{C}, 89 \%$ humidity and $26.1{ }^{\circ} \mathrm{C}, 83.9 \%$ humidity for four to five days. The active mass was calculated to observe the amount of change in the activity in accordance with the environmental changes, such as outside temperature and weather. We calculated the active mass between two spots with the location information measured in every one minute from midday to six o'clock using the following Equation (1).

$P$ : average latitude of two spots,

$d P$ : difference in the latitudes of two spots,

$d R$ : difference in the digital recordings of two spots,

$M$ : radius of curvature of a meridian,

$$
M=\frac{6356752.31}{{\sqrt{\left(1-0.006674 \sin ^{2} P\right)}}^{3}}
$$

$N$ : radius of curvature of the prime vertical

$$
N=\frac{6378137}{\sqrt{\left(1-0.006674 \sin ^{2} P\right)}}
$$




\section{RESULTS AND DISCUSSIONS}

Several external changes in the pregnant livestock were observed, such as excellent nutritive conditions, calm behavior and distended abdomen. Interestingly, the most typical change noted was estrus stopping. We regard the cattle as cow in calf when they were not sexually excited even after two to four months from mating. It was assumed that measurement of the active mass during gestational time and estrus would be an important technique for breeding management at natural pasture land. Therefore, two Korean native cattle were tested for breeding utilizing GPS receive technology. As a result, data related to the active mass of pregnant and non-pregnant cattle and travel distance by season were obtained.

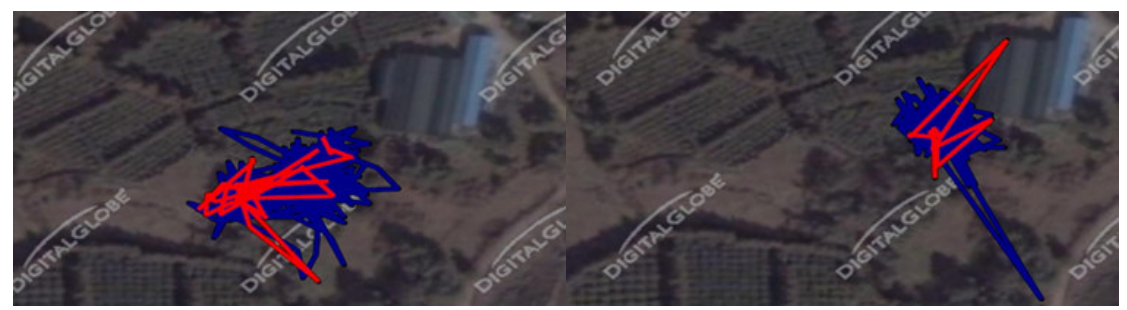

(a) 1st day

(b) 2nd day

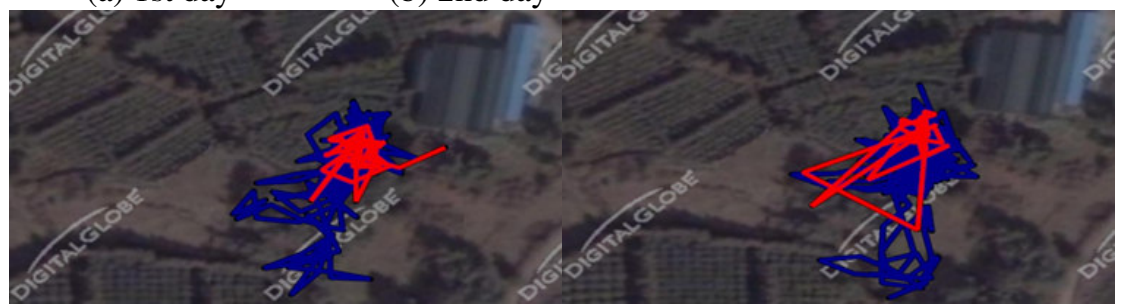

(c) 3rd day

(d) 4th day

Fig.4. Experiment at Jeju.

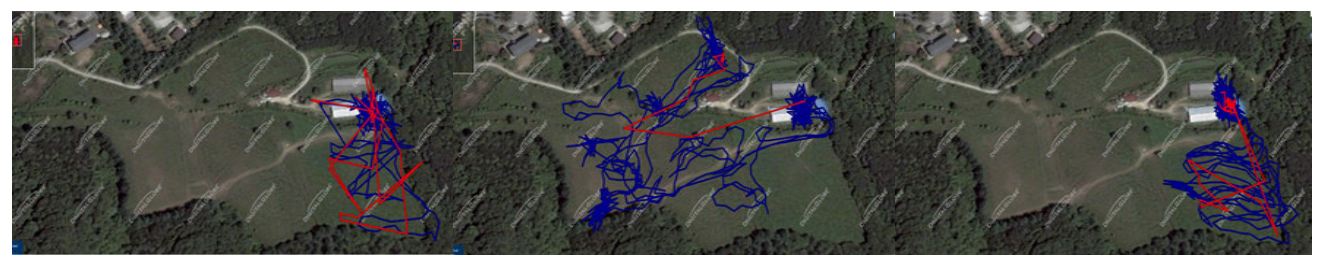

(a) 1st day

(b) 2nd day

(c) 3rd day

Fig.5. Experiment at Chuncheon.

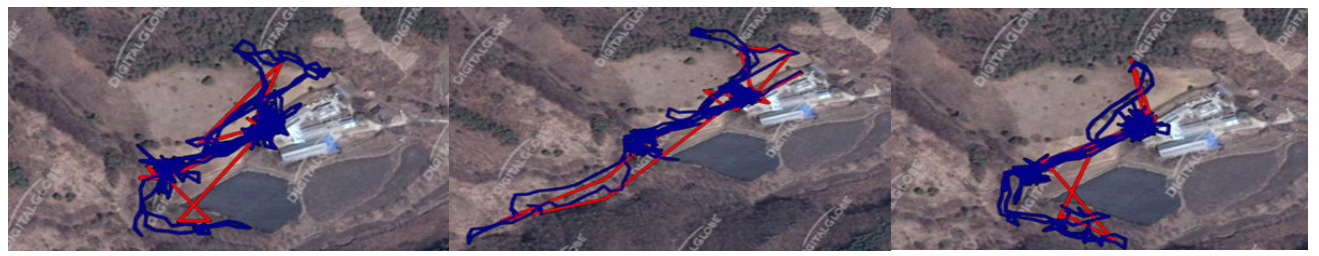

(a) 1st day

(b) 2nd day

(c) 3rd day

Fig.6. Experiment at Boeun. 
Table 2. The distance of activity and the radius of action in pasture land

\begin{tabular}{|c|c|c|c|c|c|}
\hline Division & & & Total distanc & (m) & $\begin{array}{l}\text { Average of outdoor temp. } \\
\& \text { RH }\end{array}$ \\
\hline \multirow{9}{*}{ Jeju } & \multirow{2}{*}{$1 \mathrm{st}$} & Non-pregnancy & 4,612 & \multirow{2}{*}{$\begin{array}{l}\text { about } \\
10 \text { times }\end{array}$} & \multirow{7}{*}{$7.7^{\circ} \mathrm{C}, 71.5 \%$} \\
\hline & & Pregnancy & 458 & & \\
\hline & \multirow{2}{*}{ 2nd } & Non-pregnancy & 2,545 & \multirow{2}{*}{$\begin{array}{l}\text { about } \\
14 \text { times }\end{array}$} & \\
\hline & & Pregnancy & 183 & & \\
\hline & \multirow{2}{*}{$3 \mathrm{rd}$} & Non-pregnancy & 2,474 & \multirow{2}{*}{$\begin{array}{l}\text { about } \\
7.8 \text { times }\end{array}$} & \\
\hline & & Pregnancy & 316 & & \\
\hline & \multirow{3}{*}{4 th } & Non-pregnancy & 2,817 & \multirow{3}{*}{$\begin{array}{l}\text { about } \\
7.5 \text { times }\end{array}$} & \\
\hline & & Pregnancy & 371 & & A season \\
\hline & & & & & Spring \\
\hline \multirow{7}{*}{ Chuncheon } & \multirow{2}{*}{$1 \mathrm{st}$} & Non-pregnancy & 3,805 & \multirow{2}{*}{$\begin{array}{l}\text { about } \\
3 \text { times }\end{array}$} & \multirow{5}{*}{$23.4^{\circ} \mathrm{C}, 89 \%$} \\
\hline & & Pregnancy & 1,139 & & \\
\hline & \multirow{2}{*}{ 2nd } & Non-pregnancy & 9,574 & \multirow{2}{*}{$\begin{array}{l}\text { about } \\
12 \text { times }\end{array}$} & \\
\hline & & Pregnancy & 783 & & \\
\hline & \multirow{3}{*}{$3 \mathrm{rd}$} & Non-pregnancy & 9,317 & \multirow{3}{*}{$\begin{array}{l}\text { about } \\
20 \text { times }\end{array}$} & \\
\hline & & Preonancy & 453 & & A season \\
\hline & & & & & Summer \\
\hline \multirow{7}{*}{ Boeun } & \multirow{2}{*}{1 st } & Pregnancy & 5,758 & \multirow{2}{*}{$\begin{array}{l}\text { about } \\
7 \text { times }\end{array}$} & \multirow{5}{*}{$26.1{ }^{\circ} \mathrm{C}, 83.9 \%$} \\
\hline & & $\begin{array}{l}\text { Pregnancy } \\
\text { (Last stage) }\end{array}$ & 809 & & \\
\hline & 2nd & Pregnancy & 4,412 & \multirow{2}{*}{$\begin{array}{l}\text { about } \\
4.5 \text { times }\end{array}$} & \\
\hline & & $\begin{array}{l}\text { Pregnancy } \\
\text { (Last stage) }\end{array}$ & 980 & & \\
\hline & \multirow{3}{*}{$3 \mathrm{rd}$} & Pregnancy & 4,526 & \multirow{3}{*}{$\begin{array}{l}\text { about } \\
4 \text { times }\end{array}$} & \\
\hline & & Pregnancy & 1032 & & A season \\
\hline & & (Last stage) & & & Summer \\
\hline
\end{tabular}

There was a defined difference of active mass based on pregnancy, as listed in Table 2. We believe that we could predict the active mass and pattern of pregnant cattle using GPS. We anticipated that stock farms may predict the body symptoms of Korean native cattle and handle a situation promptly by checking the data in real time.

\section{CONCLUSIONS}

This research was performed to utilize in feeding and management of pasture land tracking mobile type of pastureland and active mass of cattle based on pregnancy and external environmental change such as change of temperature with humidity by GPS. 
We wanted to analyze the active mass and pattern with collected data with regard to pregnancy and disease through additional test, and check whether we can grasp the rearing information through difference amount of Korean native cattle action in accordance with altitude and gradient of pastureland, mating season and birth timing.

\section{ACKNOWLEDGEMENT}

This research was supported by Bio-industry Technology Development Program, Ministry for Food, Agriculture, Forestry and Fisheries, Republic of Korea.

\section{REFERENCES}

Agouridis, C.T., Koostra, B.K., Edwards, D.R., Stombaugh, T.S., Vanzant, E.S. and Workman, S.R. (2004). Suitability of a GPS collar for grazing studies. Transactions of the ASAE 47(4), 1321 - 1329.

AFRC. (1993). Agricultural and food research council. Energy and protein requirements of ruminants. Wallingford: CAB International, 159.

ARC .(1980). Agricultural research council. The nutrient requirements of ruminant livestock. Farnham Royal: Commonwealth Agricultural Bureaux, 351.

Barbari, M., L. Conti., B.K. Koostra, G., Masi, F.S., Guerri and Workman, S.R. (2006). The Use of Global Positioning and Geographical Information Systems in the Management of Extensive Cattle Grazing. Biosystems Engineering, 95(2), 271 - 280.

Chowdappa, R., N. Hasegawa, M., Goto, M., Kozono, T., Fujishiro, T., Takahashi, M., Takagi, K., Nogami and Sonoda, T. (2005). Behavior and Ruminal Characteristics of Japanese Black Cattle Grazing in Forest of Young Tree Plantation and Native Grassland. Animal Behavior and , 41(3), 49 - 156.

Chun M.S. (2004). Origin of veterinary and domestication of wild animals. Journal of the Korean Veterinary Medical Association. 40(10), 957 - 959 (In Korean).

CSIRO. (1990). Commonwealth scientific and industrial research organization. Feeding Systems for Australian Livestock: Ruminants. Melbourne: CSIRO Publications, Australia.

Eugene D. Ungar, Zalmem Henkin, Mario Gutman, Amit Dolev, Avrabam Genizi and David Ganskopp. (2005). Inference of Animal Activity From GPS Collar Data on Free-Ranging Cattle. Rangeland Ecology and Management, 58(3), 256 - 266.

FOX, D.G., SNIFFEN, C.J., O'CONNOR, J.D. et al. (1992). A net carbohydrate and protein system for evaluating cattle diets: III. Cattle requirements and diet adequacy. J. Anim. Sci., 70,3578 - 3596 .

Ganskopp D. (2001). Manipulating cattle distribution with salt and water in large arid-land pastures: a GPS/GIS assessment. Applied Animal Behaviour Science, 73, 251 - 262.

Harbin, M. (1995). Track'emcowboy: GPS rides the range. GPS Would, 6(9), 20 - 34. 
HIRAKAWA M., L. Zhang, T. HIRAYAMA, M. MATSUNAGA and K. KATOH. (2006). Technique on the Measurement of Eating and Ruminating Behavior for Grazing Cattle. Journal of Japanese Society of Livestock Management , 42(3), 168 - 173 (In Japanese).

Jeffrey S. Fehmi and Emilio A. Laca. (2001). A note on using a laser-based technique for recording of behaviour and location of free-ranging animals. Applied Animal Behaviour Science, 71, 335 - 339.

Kim H. T., H. J. Ko, K. Y. Kim, T. Nishizu and H. L. Choi. (2006). A Farm Scale Study on the Modified Ventilation System for Improving Environmental Factors in a Confined NurseryPigBuilding. Journal of Biosystems Engineering, 31(3), 175 - 181 (In Korean). 